\title{
GLOBALIZATION AND FOREIGN AMENITY MIGRANTS: THE CASE OF FOREIGN HOME OWNERS IN THE POMURSKA REGION OF SLOVENIA
}

\author{
Barbara Lampič ${ }^{1}$, Irena $\mathrm{Mrak}^{2}$
}

Received 26 May 2011; Accepted 16 December 2011

\begin{abstract}
Slovenia became an independent state in 1991 with immigration flows in the country strengthening since 1998. The majority of the immigrants, mostly seeking employment, originate from the former Yugoslav republics. Parallel to this work migration flow from the south and after accession to the EU, Slovenia also attracted other types of migration from EU member states particularly amenity migrants. These amenity migrants show a strong interest in the Slovenian peripheral rural regions with its reasonably priced real estate and its natural landscape character. In the case of these foreign home owners an important question is whether and to what extent they are symptomatic of the processes of globalization? To address this, a detailed survey has been conducted in the Pomurska region located in eastern Slovenia and bordering Hungary, Austria and Croatia. The survey focused on foreign home owners who either became permanent residents or who are second home owners. The results of this empirical work prove very insightful of the processes going on in the region and the integration of migrants into rural society in Slovenia.
\end{abstract}

Keywords: Globalization, migration, foreign home owners, real estate purchases, qualitative interviews, Pomurska region, Slovenia

Abstract: Slovenija se je osamosvojila leta 1991, priseljevanje pretežno iz območij bivših jugoslovanskih republik pa se je okrepilo predvsem po letu 1998. Prevladovali so delovni migranti, $z$ vstopom Slovenije $\vee$ EU pa se je povečalo zanimanje tudi iz drugih držav članic. Če so se priseljenci, ki so iskali delo, selili predvsem $\checkmark$ regionalna in gospodarsko močna središča, so migracije na podeželje $v$ veliki meri povezane z veliko privlačnostjo (naravnega) okolja, istočasno pa so (bile) cenovno zelo dostopne tudi nepremičnine. $\mathrm{V}$ primeru tujcev oziroma tujih lastnikov nepremičnin (hiš) na podeželju se sproža vprašanje, ali so le-ti nosilci ali že učinek globalizacije $v$ širšem evropskem prostoru? Prav zato je bila izvedena raziskava med tujci v Prekmurski statistični regiji, ki leži na skrajnem vzhodu Slovenije in meji na

\footnotetext{
${ }^{1}$ Doc. Dr. Barbara Lampič, Department of Geography, Faculty of Arts, University of Ljubljana, Aškerčeva 2, Ljubljana, Slovenia, email: barbara.lampic@ff.uni-lj.si

2 Doc. Dr. Irena Mrak, Department of Geography, Faculty of Arts, University of Ljubljana, Aškerčeva 2, Ljubljana, Slovenia email: irena.mrak@siol.net
} 
Avstrijo, Madžarsko in Hrvaško. Osredotočili smo se na tuje lastnike nepremičnin, ki bodisi $v$ regijo prihajajo le občasno in so lastniki počitniških bivališč ali pa so že stalno priseljeni. Rezultati intervjujev s priseljenci osvetljujejo ta nov pojav v regiji pa tudi procese njihovega vključevanja družbo.

\section{Introduction}

Increased mobility of people is one of the key dimensions of globalization. It consists of several individual elements that contribute to the "globalization of mobility" - tourism, labor (economic/working) migration, amenity migration and counter-urbanization (Woods, 2010). Amenity migration, an increasingly recent form of migration, is one impact of globalization present in rural areas where aesthetic, recreational, and other consumption-oriented values are sought. Such "rural amenities" refer to the hedonic, or pleasurable, aspects associated with natural and man-made features of rural areas, including wilderness, agricultural landscapes, historic structures, and cultural traditions (Organization for Economic Cooperation and Development, 1999, cited in Marcouiller et al., 2002) and also the more specific regional characteristics directly associated with nature (land, water etc.). The values of these amenities are driven by human perceptions (Marcouiller et al., 2002). The availability of amenities in a certain region stimulates amenity migrants (i.e. recreational home owners, teleworkers, retirees, and tourists) to come to the region (Marcouiller, Clendenning and Kedzior, 2002). Conversely amenity migration (the majority of whom become second home owners) reshape local landscapes with global economic dynamics ever more visibly reflected in local property dynamics (Cadieux, Hurley, 2009). Pitkänen (2008) argues that second homes are increasingly popular in modern societies as a result of better material well-being with an essential motive to purchase and use a second home often being the landscape characteristics. Schmid (2005) and Williams et al. (2004) note that the majority of second home owners in many European countries are foreign purchases. Schmid (2005) also points to the importance of increased average acceptable distance between first and second homes, and that cheap air travel across European countries has affected such expansion. Development and transformations of transport systems (road, rail and air travel) have also brought greater accessibility and are a key factor for the internationalization of second homes (Williams et al. 2004). Geographically, second home ownership has spread significantly with regions of Central and Eastern Europe currently among the most popular destinations.

Several researchers have pointed to the important contribution of second homes to regional economies as well as their importance in maintaining the cultural landscape and the ongoing use of buildings (Hall and Müller, 2004). The "amenity property boom" in past years is affecting a far more extensive set of rural areas around the world than previous booms of this sort. Several case studies and more systematic approaches show that increases in the mobility of elites, rapid growth in relative and absolute incomes of certain classes of urban professionals, loosening of restrictions on foreign ownership of property in many countries, ongoing reductions in the friction of distance through developments in transportation and communications technologies, and the increased circulation of representations of prized rural landscapes have all contributed to the formation of an increasingly globalized market for a relatively small number of specific rural landscapes meeting the requisite criteria (McCarthy, 2008).

In Slovenia we have a relatively young country; having gained independence in 1991, becoming part of the European Union in 2004 and the Schengen area on $21^{\text {st }}$ of December 2007. Due to its historical connections with the former Yugoslav republics, the increasing number of immigrants from former Yugoslavia after its independence was expected. Immigration flows in the country have been on the increase since 1998 following economic recovery in the country. Parallel to work migration flows the country also became of interest to other types of migration. This was particularly evident following accession to the European Union. Amenity migrants showed a strong interest in Slovenian peripheral rural regions and their reasonably priced real estate with 3,576 real estate purchases completed by the end of 2010 (Tax Administration of the RS, 2010). In fact these migrants (most often second home owners) while being somewhat of a novelty especially in traditional rural regions, engendered a different "value" of peripheral 
rural space by their presence, attitude and recognition of the high quality living environment. The majority of new real estate owners are second home owners but in some regions they also settle down as permanent residents. The highest numbers of foreign real estate purchases (Great Britain $(1,213-33.9 \%)$, Italy $(1,016-28.4 \%)$ and Austria $(10.9 \%)$ dominate) prevail in four border regions; Obalno-Kraška, Goriška, Gorenjska and the Pomurska region.

In the case of the Pomurska region in Slovenia, the survey presented in this paper focused on the increasing foreign home ownership and the expansion of the transnational amenity migration which started after 2004. The Pomurska region is one of the most peripheral rural regions in Slovenia with severe population decline due to work and rural-urban migration leading to excess availability of real estate at very reasonable prices. The first foreigner homeowners (predominantly British, Austrians and Germans) arrived in the area in 2004 and 2005 buying properties at extremely low prices. As this immigration to the Pomurska region continued real estate prices grew significantly albeit in recent years, with the wider economic crisis, immigration flow has slowed considerably if not completely stopped.

\section{Migration and foreign resident real estate purchases}

Slovenia is characterized as predominantly a rural, sparsely populated, country (100 inhabitants per $\mathrm{km}^{2}$ ). Over half of the 2 million inhabitants live in small settlements. Despite its rural character immigration flows have been strong in the last few years with work migrants prevailing. These work migrants are dominated by men on a national level but interestingly on a regional level (in the case of Pomurska region for example) the share of women is much higher suggesting a different type of immigration. In this research different data bases, including foreign real estate purchases and qualitative interviews explore these trends and raise questions about the globalization processes in Slovenian rural regions.

These rural amenity migrants are attracted to the alpine Gorenjska and Goriška region, costal Obalno-kraška region and hilly Pomurska region because of their recognition as high natural amenity regions. As Walters (2002) has argued, amenity migrants are characterized by their attraction to pleasant climates, favourable economic conditions and an avoidance of large metropolitan areas. Walters (ibid.) is also convinced that the presence of (mostly natural) amenities has a significant influence on regional economic growth. In King's (1998) research on the British community in Tuscany for example, the locations chosen by this community as their place of residence highlight a number of connections among the various motives for migrating. These migrants searched for an escape from the urban environment and were drawn to the attractions of a Tuscan climate and landscape, conceiving it as a form of escape from certain perceived aspects of the contemporary world.
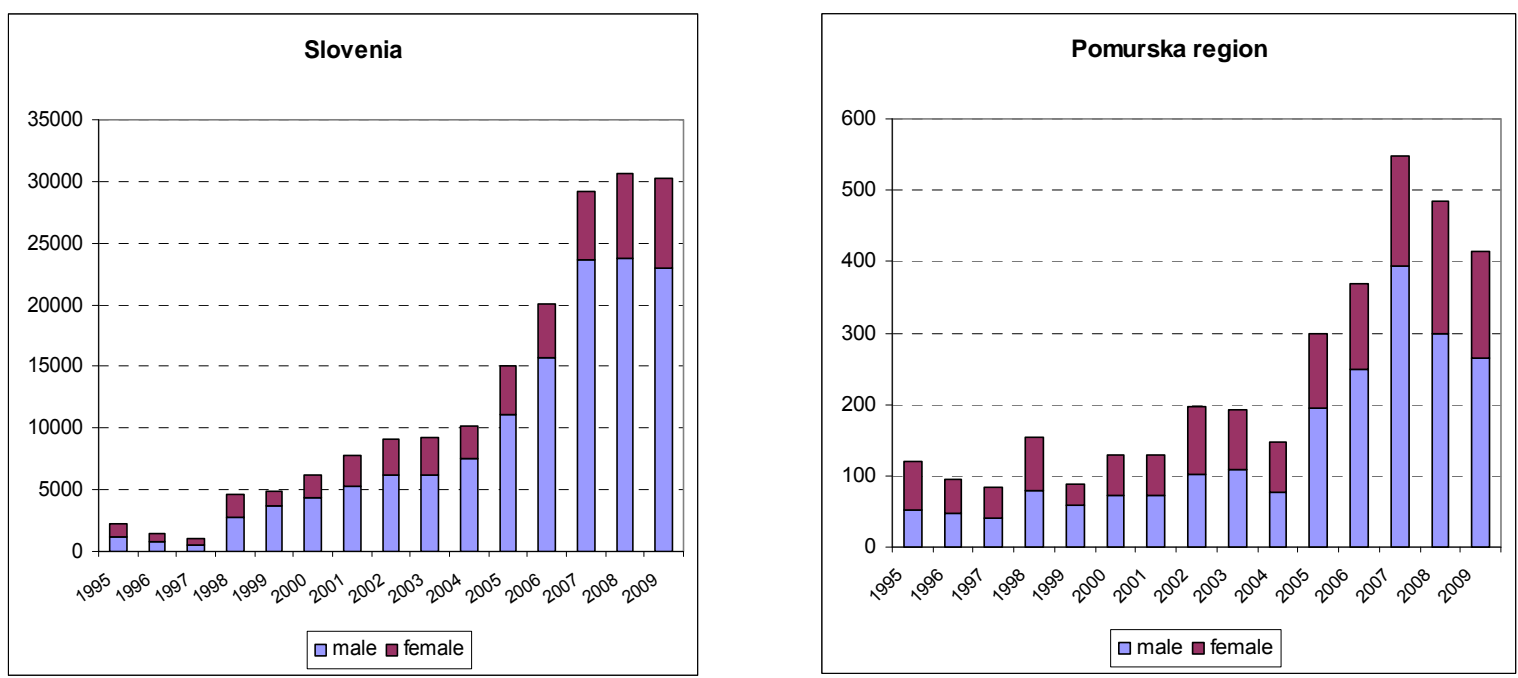

Fig 1. International immigrants to Slovenia and Pomurska region in the period from 1995 to 2009.

Source: Statistical Office of the Republic of Slovenia. International migration by citizenship, statistical regions,

Slovenia. http://pxweb.stat.si/pxweb/Dialog/varval.asp? ma=05N1042E\&ti=\&path=../Database/

Demographics/05_population/40_Migration/05_05N10_International/\&lang=1 (Accessed 7.12.2010). 
Benassi and Porciani (2010) describe amenity migrants as people who are seeking to improve their lifestyle by choosing a destination with a warmer climate, beautiful scenery and more relaxed atmosphere. He refers to two groups of amenity migrants:

- Retirement migrants who tend to move with their spouses and generally have high levels of education and who may also have a history of international mobility or tourism; and secondly

- people who want (literally) to "get off" or "get out." These are people who make the decision to abandon a previous lifestyle where they generally belonged to the uppermiddle class, often lived in big cities and led a relatively stressful existence, to "escape" and start a new life with better living conditions.

Foreign home owners in Slovenia belong to the two mentioned groups. The first, migrants from more developed countries, mostly individuals (either retired or still working), usually from urban areas, are seeking a better and different lifestyle and wish to live in a scenic and less crowded environment. The second important group of migrants are the cross-border migrants mostly from Italy (Trieste region), who are looking to live in the countryside (Obalno-kraška region) but still commute to work in Trieste. This transient group of migrants in particular provoke strong discussion amongst the local population due to their weak integration into the local area.

\begin{tabular}{|c|c|c|c|c|c|c|c|c|c|}
\hline Country & 2004 & 2005 & 2006 & 2007 & 2008 & 2009 & 2010 & $2004-2010$ & Structure (\%) \\
\hline Austria & 93 & 73 & 59 & 62 & 41 & 27 & 34 & 389 & 10.9 \\
\hline Belgium & 7 & 3 & 5 & 9 & 4 & 6 & 9 & 43 & 1.2 \\
\hline Bulgaria & 0 & 0 & 0 & 4 & 4 & 2 & 3 & 13 & 0.4 \\
\hline Cyprus & 0 & 0 & 3 & 0 & 4 & 0 & 0 & 7 & 0.2 \\
\hline Czech Republic & 0 & 1 & 1 & 3 & 2 & 3 & 1 & 11 & 0.3 \\
\hline Denmark & 2 & 2 & 2 & 0 & 1 & 0 & 0 & 7 & 0.2 \\
\hline Other non EU & 8 & 15 & 20 & 25 & 41 & 22 & 28 & 159 & 4.4 \\
\hline Estonia & 0 & 0 & 0 & 0 & 0 & 1 & 0 & 1 & 0.0 \\
\hline Finland & 0 & 0 & 3 & 1 & 3 & 0 & 0 & 7 & 0.2 \\
\hline France & 7 & 17 & 18 & 17 & 6 & 13 & 8 & 86 & 2.4 \\
\hline Greece & 0 & 2 & 2 & 1 & 0 & 1 & 0 & 6 & 0.2 \\
\hline Ireland & 9 & 37 & 11 & 20 & 12 & 7 & 4 & 100 & 2.8 \\
\hline Italy & 121 & 123 & 185 & 218 & 154 & 120 & 95 & 1,016 & 28.4 \\
\hline Latvia & 0 & 0 & 0 & 0 & 1 & 0 & 0 & 1 & 0.0 \\
\hline Lithuania & 0 & 0 & 1 & 0 & 2 & 0 & 0 & 3 & 0.1 \\
\hline Luxembourg & 0 & 0 & 0 & 1 & 0 & 0 & 0 & 1 & 0.0 \\
\hline Hungary & 3 & 2 & 1 & 5 & 3 & 8 & 1 & 23 & 0.6 \\
\hline Malta & 0 & 0 & 2 & 0 & 0 & 0 & 0 & 2 & 0.1 \\
\hline Germany & 68 & 77 & 34 & 34 & 43 & 33 & 27 & 316 & 8.8 \\
\hline Holland & 10 & 9 & 15 & 12 & 16 & 5 & 11 & 78 & 2.2 \\
\hline Poland & 1 & 0 & 3 & 0 & 4 & 2 & 2 & 12 & 0.3 \\
\hline Portugal & 3 & 0 & 0 & 0 & 0 & 1 & 0 & 4 & 0.1 \\
\hline Romania & 0 & 0 & 0 & 1 & 0 & 2 & 2 & 5 & 0.1 \\
\hline Slovakia & 2 & 1 & 1 & 1 & 4 & 0 & 1 & 10 & 0.3 \\
\hline Spain & 3 & 9 & 2 & 1 & 0 & 0 & 1 & 16 & 0.4 \\
\hline Sweden & 2 & 11 & 12 & 9 & 5 & 6 & 2 & 47 & 1.3 \\
\hline Great Britain & 104 & 260 & 360 & 306 & 122 & 27 & 34 & 1,213 & 33.9 \\
\hline All together & 443 & 642 & 740 & 730 & 472 & 286 & 263 & 3,576 & 100.0 \\
\hline
\end{tabular}

Tab 1. Number of foreign real estate purchases in Slovenia by the citizenship of the new owners. Source: Tax Administration of the Republic of Slovenia. 2010. Data of foreign home purchases for the period of $2005-2010$.

There is also within this migration a spatial pattern of foreign purchases that should be emphasized as it displays great differences within the regions; in western Slovenia the cross 
border migrants from Italy prevail while in Gorenjska and mostly the Pomurska region amenity migrants from Great Britain, Austria and Germany are dominant. However due to the fact that the costs of living in Slovenia are becoming similar to the more developed EU members states, coupled to the recent economic crisis, the interest in real estate purchasing is diminishing and new major immigration flows cannot be expected. On the contrary emigration is starting to arise especially in the case of work migrants from former Yugoslav republics - these migrants were employed mostly in the construction industry and due to the major crisis in this sector they are the first to leave Slovenia in search of new opportunities elsewhere.

\begin{tabular}{|c|c|c|c|c|c|c|c|c|c|c|}
\hline $\begin{array}{l}\text { Statistical } \\
\text { region }\end{array}$ & 2004 & 2005 & 2006 & 2007 & 2008 & 2009 & 2010 & $\begin{array}{l}2004- \\
2010\end{array}$ & $\begin{array}{l}\% \text { of all } \\
\text { purchases }\end{array}$ & $\begin{array}{l}\text { Number of } \\
\text { inhabitants (2010) }\end{array}$ \\
\hline Gorenjska & 49 & 119 & 95 & 84 & 34 & 24 & 15 & 420 & 11.7 & 202,903 \\
\hline Goriška & 48 & 92 & 150 & 121 & 74 & 37 & 41 & 563 & 15.7 & 119,080 \\
\hline $\begin{array}{l}\text { Jugovzhodna } \\
\text { Slovenija }\end{array}$ & 13 & 24 & 14 & 11 & 12 & 3 & 4 & 81 & 2.3 & 142,092 \\
\hline Koroška & 0 & 0 & 18 & 12 & 7 & 6 & 9 & 52 & 1.5 & 72,812 \\
\hline $\begin{array}{l}\text { Notranjsko- } \\
\text { kraška }\end{array}$ & 4 & 23 & 11 & 11 & 13 & 4 & 9 & 75 & 2.1 & 52,217 \\
\hline Obalno-kraška & 115 & 105 & 153 & 164 & 122 & 105 & 83 & 847 & 23.7 & 110,412 \\
\hline $\begin{array}{l}\text { Osrednjeslovens } \\
\text { ka }\end{array}$ & 26 & 39 & 35 & 31 & 40 & 15 & 19 & 205 & 5.7 & 529,646 \\
\hline Podravska & 48 & 65 & 65 & 67 & 31 & 26 & 28 & 330 & 9.2 & 323,343 \\
\hline Pomurska & 95 & 118 & 125 & 142 & 93 & 45 & 33 & 651 & 18.2 & 119,548 \\
\hline Savinjska & 33 & 28 & 51 & 57 & 39 & 13 & 19 & 240 & 6.7 & 260,025 \\
\hline Spodnjeposavska & 10 & 28 & 20 & 27 & 7 & 8 & 2 & 102 & 2.9 & 70,192 \\
\hline Zasavska & 2 & 1 & 3 & 3 & 0 & 0 & 1 & 10 & 0.3 & 44,706 \\
\hline Slovenia & 443 & 642 & 740 & 730 & 472 & 286 & 263 & 3576 & 100.0 & $2,046,976$ \\
\hline
\end{tabular}

Tab 2. The foreign real estate purchases by statistical regions of Slovenia in the period from 2004 to 2010. Source: Tax Administration of the Republic of Slovenia. 2010. Data of foreign home purchases for the period of $2005-2010$.

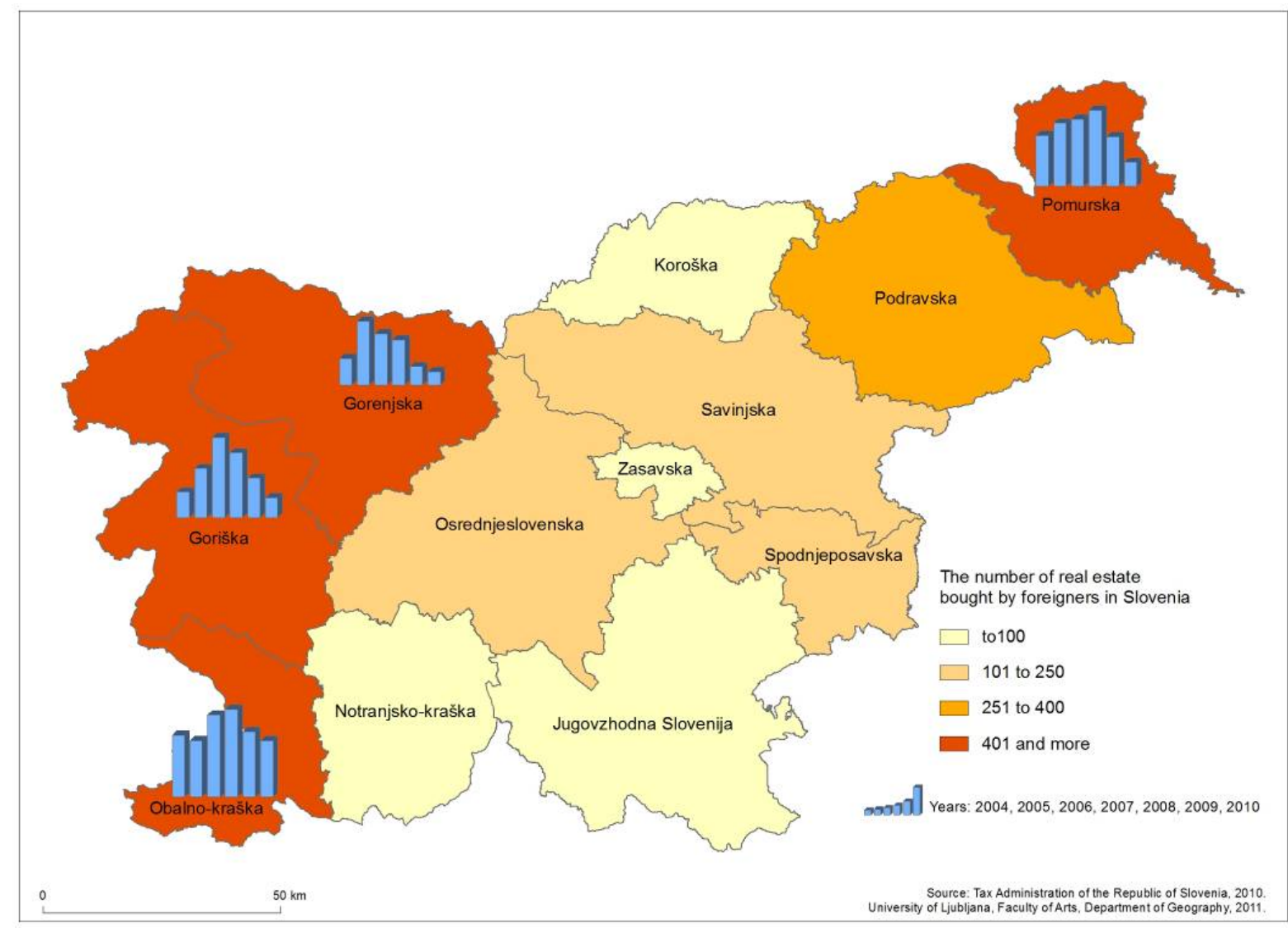

Fig 1. Foreign purchases in the statistical regions of Slovenia. 
The spatial pattern of foreign purchases shows that nearly $24 \%$ of all purchases (in the period from 2004 to 2010) were in the Obalno-kraška region. A fall off in the yearly number of purchases is very obvious in the Gorenjska region (from 119 in the year 2005 to just 15 in 2010), the Spodnjeposavska region (from 28 in 2005 to just 2 in 2010) and in the Pomurska region, where the total number of yearly purchases dropped from 142 (in 2007) to 33 in 2010. However, all together over $18 \%$ of foreign purchases in 2010 still occurred in the Pomurska region. Further, although Slovenia remains challenged by the broader economic crisis, with GDP growth at $1.2 \%$, which is lower than the average growth in the Euro area, in 2010 the recorded sales of apartments in Slovenia was up by $30 \%$ and sale of single- and two-family houses was up by $56 \%$ compared to 2009 . Such an increase in residential property transactions seems to indicate a revival of the property market (Surveying and Mapping Authority of the Republic of Slovenia, 2011), albeit its future trajectory remains uncertain.

\section{Foreign home owners in the Pomurska region}

The Pomurska region contains the hilly area of Goričko to the north and lowlands around the river Mura to the south. To the west it is limited by the state border between Slovenia and Austria along the Kučnica stream. The population of 121,824 represents $6 \%$ of the entire population of Slovenia (SURS, 2010). The region is predominantly rural with Murska Sobota being the regional centre as well as the most urbanized area within the Pomurska region. Traditionally the area has been peripheral; politically and ethnically as well as economically. Inhabitants depend on agriculture and seasonal work and agriculture was and still is limited and affected by the remains of the Hungarian feudal social regime, land division and inheritance system. As such, historically, the region suffered outmigration and it was only in the past decade that the trend of immigration began. After Slovenia entered the EU, citizens from other EU countries (mostly Great Britain, Austria, Germany, Italy and Ireland) started to purchase real estate in the region, a phenomenon that had not been experienced before.

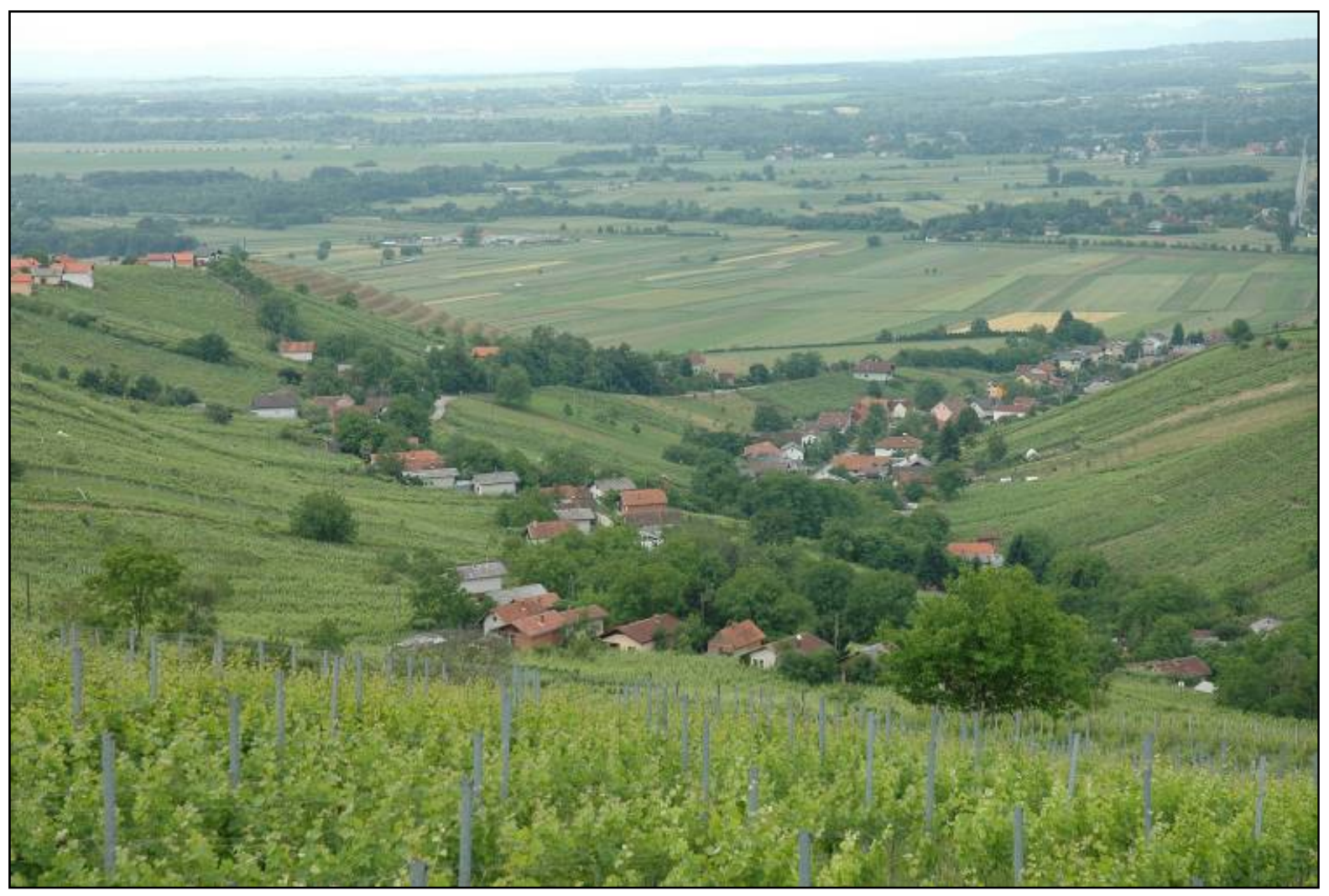

Fig 3. The landscape of Pomurska region.

From May 2004 to the end of 2010651 (out of 3576 in all of Slovenia) foreigners bought real estate in the Pomurska region. In relation to other countries the figures are not high but from the Slovene perspective this new process marked the whole area and its population 
significantly. The share of permanent inhabited dwellings per 1000 inhabitants in the Pomurska region is lower than in other Slovenian regions. Over $11 \%$ of domiciles are permanently uninhabited and, before Slovenia joined the EU (in 2002) over 2,500 uninhabited dwellings, for sale at a very low price, were recorded in the whole region (Pavlin, 2009). In the period from 2004 to 2008 the average price per $\mathrm{m}^{2}$ (in a private house) in the Pomurska region reached just $56 \%$ of the prices on average of a Slovenian house (Pavlin, 2009). This generated huge interest from foreign purchasers of real estate (UK citizens dominate (nearly half in the whole period), but also the share of Austrians, Germans and Italians is high) reaching its highest in 2006 and 2007 and falling back in recent years due to the economic crisis.

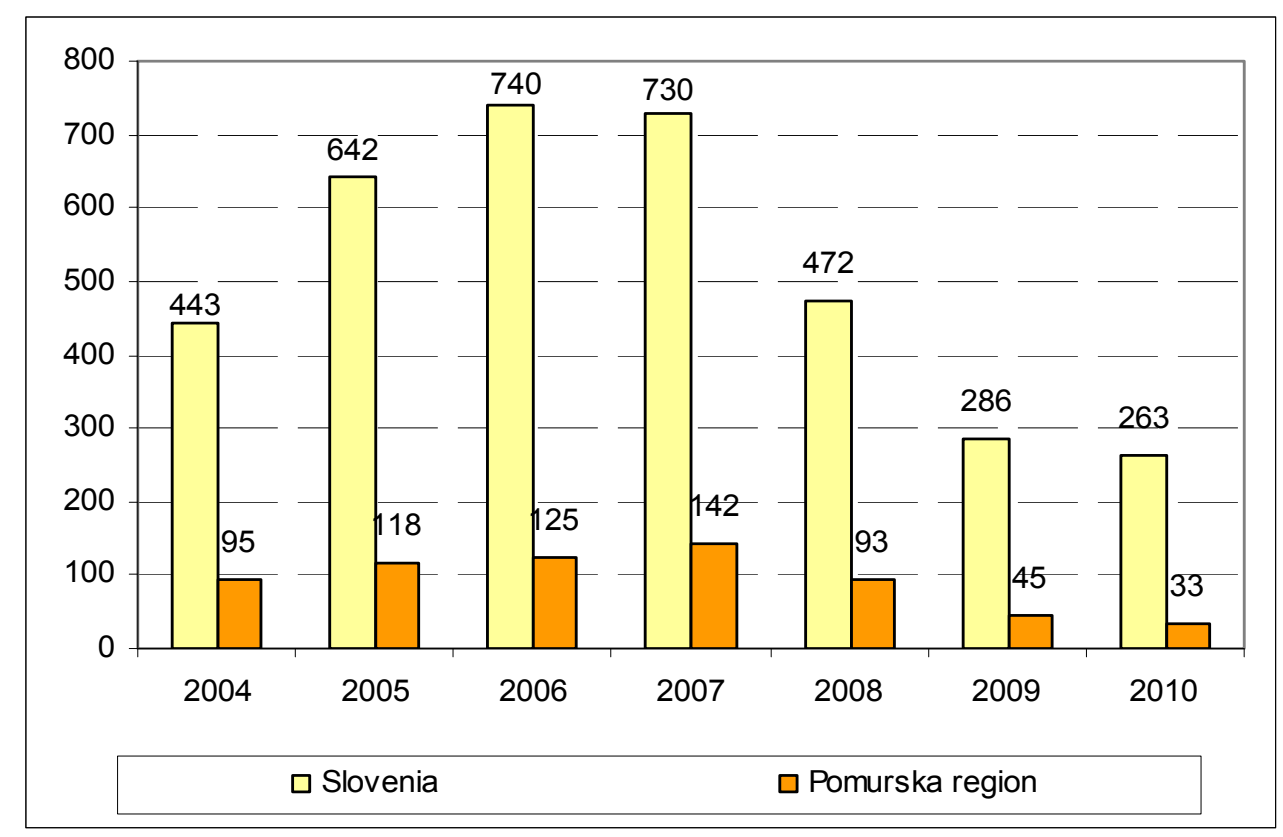

Fig 4. Purchases of real estate in Slovenia and the Pomurska region by foreign citizens (2004 - 2010$).$ Source: Tax Administration of the Republic of Slovenia. 2010. Data of foreign home purchases for the period of $2005-2010$.

In order to identify the factors impacting the purchase of real estate in the Pomurska region and to understand the process of integration of foreign home owners in the region's society, 13 qualitative interviews were conducted ${ }^{3}$ between the $20^{\text {th }}$ November 2009 and $22^{\text {nd }}$ March 2010. A total of 17 questions, relating to personal background, motives to come to the region, details about the purchase of real estate, social networks in the region and future plans, were asked. Each interview was recorded, transcribed and the answers analyzed according to the main groups of questions by each respondent. Additionally the results were compared and interpreted in the final stage. Where applicable the most representative quotes have been used to support the discussion and analysis in the remainder of this paper.

The respondents were aged between 28 and 66 years old, 5 of whom were women. Their nationality was mostly British, two respondents were from Austria and two from the United States. Their level of education varied from vocational trainee to Masters Degree. In terms of occupational status the majority were still active with 3 of the respondents retired. While their fields of education are very different it seemed quite common for them to work (full or part-time) as English teachers in the Pomurska region. In terms of other traits, 5 respondents were second home owners who come to the area to spend their holidays, usually less than 4 month per year; 8 respondents are permanent settlers who work in the region, and are mostly self employed. The prevailing form of the family status is "couple" with four of the respondents having children. The most common net income of the respondents is $€ 1,000-€ 1,500$ per month. The majority of the respondents came from a rural area with just 5 respondents coming from urban areas.

\footnotetext{
${ }^{3}$ The survey was conducted in the frame of 7FP project DERREG Developing Europe's Rural Regions in the Era of Globalization (2009-2011) www.derreg.eu.
} 
The majority of the respondents came to live in the Pomurska region or to purchase their second home between 2001 - 2005, 2 came in 2006 and the remainder from 2007 on. Their knowledge of Slovenia and the Pomurska region prior to their arrival was very basic and in most cases they had no real idea about the country. Some arrived to Slovenia as tourists, others came to visit a family member who was already living in Slovenia and others came to study in Slovenia and later on decided to stay in the region permanently: "I arrived to Slovenia by coincidence. My original plan was to buy property in Croatia, at the Dalmatian coast. On return I stopped in Slovenia and I liked it, so I abandoned my plans in Croatia and decided to buy a property here."

\begin{tabular}{|l|c|c|c|c|c|c|c|c|c|}
\hline Country & $\mathbf{2 0 0 4}$ & $\mathbf{2 0 0 5}$ & $\mathbf{2 0 0 6}$ & $\mathbf{2 0 0 7}$ & $\mathbf{2 0 0 8}$ & $\mathbf{2 0 0 9}$ & $\mathbf{2 0 1 0}$ & $\mathbf{2 0 0 4} \mathbf{- 2 0 1 0}$ & Structure (\%) \\
\hline Austria & $\mathbf{2 9}$ & $\mathbf{3 0}$ & $\mathbf{2 5}$ & $\mathbf{2 9}$ & $\mathbf{2 4}$ & $\mathbf{1 0}$ & $\mathbf{1 1}$ & $\mathbf{1 5 8}$ & $\mathbf{2 4 . 3}$ \\
\hline Belgium & 2 & 0 & 0 & 1 & 0 & 0 & 0 & $\mathbf{3}$ & 0.5 \\
\hline Bulgaria & 0 & 0 & 0 & 2 & 1 & 0 & 0 & $\mathbf{3}$ & 0.5 \\
\hline Other non EU & 1 & 1 & 2 & 1 & 2 & 0 & 0 & $\mathbf{7}$ & 1.1 \\
\hline Finland & 0 & 0 & 0 & 0 & 1 & 0 & 0 & $\mathbf{1}$ & 0.2 \\
\hline France & 2 & 1 & 0 & 1 & 1 & 6 & 4 & $\mathbf{1 5}$ & 2.3 \\
\hline Ireland & 1 & 0 & 2 & 1 & 1 & 1 & 0 & $\mathbf{6}$ & 0.9 \\
\hline Italy & $\mathbf{2}$ & $\mathbf{1 4}$ & $\mathbf{7}$ & $\mathbf{1 9}$ & $\mathbf{8}$ & $\mathbf{2}$ & $\mathbf{3}$ & $\mathbf{5 5}$ & $\mathbf{8 . 4}$ \\
\hline Hungary & 0 & 0 & 0 & 2 & 1 & 3 & 0 & $\mathbf{6}$ & 0.9 \\
\hline Germany & $\mathbf{9}$ & $\mathbf{1 9}$ & $\mathbf{7}$ & $\mathbf{1 0}$ & $\mathbf{1 3}$ & $\mathbf{7}$ & $\mathbf{6}$ & $\mathbf{7 1}$ & $\mathbf{1 0 . 9}$ \\
\hline Holland & 3 & 0 & 1 & 1 & 1 & 1 & 2 & $\mathbf{9}$ & 1.4 \\
\hline Poland & 0 & 0 & 1 & 0 & 0 & 2 & 1 & $\mathbf{4}$ & 0.6 \\
\hline Romania & 0 & 0 & 0 & 1 & 0 & 0 & 0 & $\mathbf{1}$ & 0.2 \\
\hline Spain & 0 & 2 & 0 & 0 & 0 & 0 & 0 & $\mathbf{2}$ & 0.3 \\
\hline Sweden & 2 & 1 & 0 & 2 & 0 & 2 & 0 & $\mathbf{7}$ & 1.1 \\
\hline Great Britain & $\mathbf{4 4}$ & $\mathbf{5 0}$ & $\mathbf{8 0}$ & $\mathbf{7 2}$ & $\mathbf{4 0}$ & $\mathbf{1 1}$ & $\mathbf{6}$ & $\mathbf{3 0 3}$ & $\mathbf{4 6 . 5}$ \\
\hline All together & $\mathbf{9 5}$ & $\mathbf{1 1 8}$ & $\mathbf{1 2 5}$ & $\mathbf{1 4 2}$ & $\mathbf{9 3}$ & $\mathbf{4 5}$ & $\mathbf{3 3}$ & $\mathbf{6 5 1}$ & $\mathbf{1 0 0 . 0}$ \\
\hline
\end{tabular}

Tab 3. The number of foreign purchasers in Pomurska region by the country of origin. Source: Tax Administration of the Republic of Slovenia. 2010. Data of foreign home purchases for the period of $2005-2010$.

The prevailing way to find a house in the Pomurska region was through advertisement in the newspaper or over the internet. Some came to the area deliberately to search for a property, others had friends in the region and bought a property with their help, another used the real estate agent; one found the property while on holiday, and two respondents used family ties in the region. Discussing the motivation to come to the Pomurska region the role of hard (good transport connections, price of housing, cost of living, public social infrastructure, public and private services) and soft factors (quality of the environment, friends, local culture, recreational activities etc.) were valorised. Among the main motives were three factors; the very low price of housing in the region (an ordinary house could be up to 15 times cheaper than in the Ljubljana region); the low cost of living (from the foreign homeowners perspective) and, the flourishing of the low cost airline connections (for example, London - Graz). Additionally there was a very important role played by a British citizen who started to advertise the idyllic countryside of Slovenia (the hilly Goričko for example) on the internet in 2004 and 2005. After coming to the region in the 1990s and marrying a Slovenian, he began buying and renovating a number of dilapidated houses in the region. This combined, in a way, both the attraction of hard factors such as the price of housing, cost of living, transport connections, good services and public social infrastructure with the soft factors of local culture; slow and peaceful life; recreational and leisure opportunities; quality of environment/climate; friends and other relations; schooling opportunities, which motivated people to move to the region: "Slovenia seems to be a safe area, especially for children. People are not moving out of Slovenia which means that living here is good. I like the landscape, especially the location of our house with a great view over our own vineyard. We are really happy here"; while another suggested that: "Beside the prices of old houses accessibility is the mayor factor to move here. At the same time, from Goričko hilly area 
you can reach three countries (Austria, Hungary and Croatia) in a very short time. To reach the neighbourhood country you need less time than from home to the first city in Britain."

The survey also focused on the process of integration of migrants into rural society. The answers showed the great experience the respondents had with the local population. All of them referred to the kindness of their neighbours and the broader population of the area. Initially local inhabitants were often curious about the new settlers but they quickly accepted them and they now feel part of the region and its population. One stumbling block initially was the bureaucratic nature of the paper work regarding their stay in the region and the purchase and/or renovation of the houses. Respondents declared that they would usually get some help from their friends or previous house owners but that they struggled with bureaucracy and very poor language (English) knowledge of officials as well as the notorious reporting to the local police office. One of the interviewees pointed out: "The paper work is most problematic. Slovenia is just not aware to be a part of the EU and I have to report at the local police station every two weeks while I am in the area." The second representative quote focuses on the problematic paper work "It was very hard at the beginning, especially to work with the official institutions. Paper work was terrible and no one spoke English."

Apart from the permanent settlers (foreign home owners) the second home owners usually stay in the region for less than six months with some having plans in the near future to live in the area permanently. Others would like to spend more time at their second homes although this is often constrained by family ties in their home country. The most positive aspect of living (or staying at the second home) often mentioned is the great landscape and the very nice and kind local population. Individually they have also mentioned the slow pace of life, no heavy traffic, overall good quality of living and options for free time activities, low house pricing in the region and the regions good accessibility: "I feel happy in Slovenia and I do not miss England. I like the fact of having all the services nearby, so we do not need to drive for too long. The kids were thrilled to go and live somewhere other than England as well... I really like the tradition here, it is very strong, especially the cultural tradition." In general they came to the area without knowing anybody but managed to establish a circle of friends, usually with the local population or with other foreign home owners of same nationality (especially the British tend to have friends among each other) really fast: "We have found friends in the area fast and they helped us to acclimatize well in the area; now we visit each other in our homes or we meet at the local bar". The most common ratio regarding the nationality of friends is about half/half. Some of the respondents have joined local clubs such as vine growing club, walking club, singing choirs, soccer club etc. Those respondents with children have signed them into local schools and they have a good experience with the school staff.

The foreign home owners mostly plan to continue living or having a second home in the region with the exception of one who decided to sell their house and move back to their home country. Some of the respondents plan on coming to live in the region permanently after selling their property in their country of origin or after retirement as they feel that the Pomurska region is now their home: "This is our new home now and we plan to stay here forever - people are nice and the landscape is great!"

Regarding professional opportunities in their new home the most common statement was that the working opportunities in the region were sparse: "There are no real possibilities for work in the region. Jobs are not paid well and there are too many expenses. The problem is also the language... I think I am also too qualified to be interesting for the employers...". The biggest obstacle to finding a job as well as to legalize, was seen to be the Slovene bureaucracy which is extremely tough and especially unfriendly towards foreigners: "There are possibilities to work in the area but only if the bureaucracy and the paper work in Slovenia becomes friendlier. At this point they both contribute more towards return of foreigners to their first homes or to another country.". Many of the retired respondents as well as the second home owners were simply enjoying the slow pace life in the region and usually had no plan to work in the area for money with just three respondents being able to run their businesses (tourism and art) using the internet. Being native English speakers however did have its advantages in finding some jobs particularly those in public schools or at language schools in Murska Sobota. 


\section{Discussion and conclusions}

Foreign home owners in some Slovene regions have reached relevance not only in terms of numbers, but also with their socio-economic and cultural impacts on the regional/local population. Due to the fact that the cost of living in Slovenia is similar to the more developed EU member states and that the economic crisis has affected the Slovenian economy badly, new major immigration flows in the next few years cannot be expected. The residential property market all over Slovenia is more or less frozen since 2008 and there are only some individuals still interested in purchasing a property in high amenity rural regions in Slovenia. Conversely emigration is starting to emerge especially in the case of work migrants from the former Yugoslav republics. Such migrants were employed mostly in the now collapsed construction industry and they are now leaving Slovenia in search of new opportunities elsewhere.

The case of foreign home owners in the Pomurska region represents an example of amenity migration, that is, migrants mainly moving to the region to change their lifestyle, choosing places with natural amenity, favourable climate, recreation opportunities and affordable housing. This process is strongly linked with globalization impacts - namely the enlargement of the EU and the accessibility of information about real estate, together with the opportunity to purchase property in Slovenia after 2004 when the common body of laws and practices of the EU were accepted. More personal motives of migrants include those who wished to move from their previous home countries in order to either change their living environment or find a cheaper place to live in their retirement. Buller and Hoggart (1994) wrote about the myth of the rural idyll, a situation which most of the respondents in the Pomurska region were drawn to and which proved to be an important pull factor to move to the region, along with the preserved environment and low price of housing. Another important issue in the Pomurska region was the exceptional kindness and openness of the local population to these newcomers which enabled an easy and rapid inclusion of immigrants (mostly those who decided to stay permanently) into the everyday life of the region. Due to their economic independence and sometimes individualism in the case of amenity migrants in the Pomurska region, it is difficult to talk about complete structural assimilation when the immigrants are included into all the structures of the society - the level of primary as well as secondary relations (Lukšič Hacin, 2010). It has been shown here however that local populations are happy to accept foreigners into their society and they also support them in their willingness to restore the abandoned houses in the area being particularly appreciative of the British and their efforts to value and consequently preserve the traditional style of houses of the region.

Finally, two significant impacts of foreign purchasing of real estate in Pomurska are observed. The first is the increase in prices of real estate in a region, that had previously known the most favourable real estate prices. This puts pressure on existing housing stock and forces prices up (see Hall and Müller, 2004). Secondly, the strong interest of foreigner home owners changed the attitude of the local population toward traditional housing and the entire image of the region. The strong interest of foreigner home owners in the region somehow also influenced the national interest in second home purchasing in the region and in a way changed the value of space on a regional and national level (Interview with Real estate agency "Halo dom", 2009). Further, as a result of the unfavourable economic situation in the region (also one of the globalization impacts) there are limited working opportunities for the local population as well as for foreign home owners and particularly among young migrants. Added to this, one further obstacle to purchasing a property and moving to Slovenia and one which illustrates a slow response to the globalization process now at work in the country is the cumbersome official level and its heavy bureaucracy.

\section{References}

[1] Benassi, F. \& Porciani, L. (2010). The dual demographic profile of migrants in Tuscany. In Salzmann, T., Edmonston, B. \& Raymer, J. (eds.), Demographic Aspects of Migration (pp. 209-226). Berlin: VS Verlag für Sozialwissenschaften. 
[2] Buller, H. \& Hoggart, K. (1994). International Counterurbanization: British Migrants in Rural France. Aldershot: Ashgate.

[3] Cadieux, K. V., Patrick T. \& Hurley, P. T. (2011). Amenity migration, exurbia, and emerging rural landscapes: global natural amenity as place and as process. GeoJournal, 76(4), 297-302. Doi: 10.1007/s10708-009-9335-0.

[4] Hall, M. C. \& Müller, D. K. (2004). Introduction: Second Homes, Curse or Blessing? In Hall, M. C. \& Müller, D. K. (eds.), Tourism, mobility, and second homes (pp. 3-14). Clevedon: Channel View Publications.

[5] Horvat, U. (2009). Naravno in selitveno gibanje prebivalstva v Pomurju po letu 2000. In Kikec, T. (ed.), Pomurje, trajnostni regionalni razvoj ob reki Muri (pp. 216-225), Ljubljana: Zveza geografov Slovenije; Murska Sobota: Društvo geografov Pomurja.

[6] Illès, S. \& Michalkó, G. (2008). Relationships between International Tourism and Migration in Hungary: Tourism Flows and Foreign Property Ownership. Tourism Geographies 10(1), 98-118. Doi: 10.1080/14616680701825271.

[7] Jansson, B. \& Müller, D. K. (2004). Second Home Plans Among Second Home Owners in Northern Europe`s Periphery. In Hall, M. C. \& Müller, D. K. (eds.), Tourism, mobility, and second homes (pp. 261-272). Clevedon: Channel View Publications.

[8] Lukšič-Hacin, M., ed. (2002). Seasonal work and emigration in the Pannonia space The neighborhood of Austria, Croatia, Hungary and Slovenia, Proceedings of the International Conference, Radenci, Slovenia, 22.-25. October 2002

[9] Lukšič-Hacin, M. (2010). Migracije v teoretskem diskurzu. In Štih, P., Balkovec, B. (Eds), Migracije in slovenski prostor od antike do danes, Zbirka Zgodovinskega časopisa, 39 (pp. 8-23). Ljubljana: Zveza zgodovinskih društev Slovenije.

[10] Marcouiller, D. W., Clendenning, J. G. \& Kedzior, R. (2002). Natural Amenity-Led Development and Rural Planning. Journal of Planning 16(4), 515-542. Doi: $10.1177 / 088541202400903572$.

[11] McCarthy, J. (2008). Rural geography: globalizing the countryside. Progress in Human Geography 32(1), 129-137. Doi: 10.1177/0309132507082559.

[12] Müller, D. K. \& Hall, M. C. (2004). The Future of Second Home Tourism. In Hall, M. C. \& Müller, D. K. (eds.), Tourism, mobility, and second homes (pp. 273-278). Clevedon: Channel View Publications.

[13] Office of the Government of the Republic of Slovenia for Macroeconomic Analysis and Development (2011). Economic Mirror, February 2011.

[14] Pavlin, B. (2009). Trg bivalnih nepremičnin v Pomurju 2004-2008. In Kikec, T. (ed.), Pomurje, trajnostni regionalni razvoj ob reki Muri (pp. 260-272), Ljubljana: Zveza geografov Slovenije; Murska Sobota: Društvo geografov Pomurja.

[15] Pitkänen, K. (2008). Second-home Landscape: The Meaning(s) of Landscape for Secondhome Tourism in Finnish Lakeland. Tourism Geographies 10(2), 169-192. Doi: $10.1080 / 14616680802000014$.

[16] Schmied, D. (2005). Incomers and locals in the European countryside. In Schmied, D. (Ed.), Winning and Losing: The Changing Geography of Europe`s Rural Areas (pp. 141167). Aldershot: Ashgate.

[17] Surveying and Mapping Authority of the Republic of Slovenia, 2011. Slovenian real estate market reports. http://prostor3.gov.si/ETN-JV/ (Accessed 4.5.2011).

[18] Walters, W. H. (2002). Place Characteristics and Later-Life Migration. Research on Aging 24(2), 243-277. Doi: 10.1177/0164027502242004.

[19] Williams, A. M., King, R. \& Warnes, T. (2004). British second homes in Southern Europe: Shifting Nodes in the Scapes and Flows on Migration and Tourism. In Hall, M. C. \& Müller, 
D. K. (eds.), Tourism, mobility, and second homes (pp. 97-112). Clevedon: Channel View Publications.

[20] Woods, M. (2009). Literature Review and Conceptual Framework. DERREG, WP5: Deliverable 5.1. Synthesis and Contextualisation of Research and Development of an Interpretative Model. http://www.derreg.eu/system/files/D5.1\%20DERREG\%20 Conceptual\%20Framework.pdf (Accessed 12.9.2011).

[21] Zelinsky, W. (1971). The hypothesis of the mobility transition. Geographical Review, 61(2), 219-249.

[22] Zupančič, J. (2005). Geopolitične in kulturnozgodovinske razsežnosti ozemlja med Muro in Rabo. In Prekmursko narečje, regionalna zavest in narodna pripadnost (pp. 20-33). Murska Sobota: Prekmurska narečna slovstvena ustvarjalnost. 